\title{
PAYMENTS FOR FOREST ECOSYSTEM SERVICES ACROSS EUROPE - MAIN APPROACHES AND EXAMPLES FROM SLOVAKIA
}

\author{
ZUZANA SARVAŠOVÁ ${ }^{1}$, KLÁRA BÁLIKOVÁ ${ }^{2}$ ZUZANA DOBŠINSKÁ², MARTINA \\ ŠTĚRBOVÁ ${ }^{1,2}$, JAROSLAV ŠÁLKA ${ }^{2}$
}

${ }^{1}$ Department of Forest Policy, Economics and Forest Management, National Forest Centre, Forest Research Institute Zvolen, T.G. Masaryka 22, 96001 Zvolen, Slovak republic

${ }^{2}$ Department of Forest Economics and Management, Faculty of Forestry, Technical University in Zvolen, T.G. Masaryka 24, 96001 Zvolen, Slovak republic

\begin{abstract}
Sarvašová Z., Báliková K., Dobšinská Z., Štěrbová M., Šálka J.: Payments for forest ecosystem services across Europe - main approaches and examples from Slovakia. Ekológia (Bratislava), Vol. 38, No. 2, p. 154-165, 2019.

Payments for ecosystem services (PES) are flexible, financial mechanisms for utilisation of available finances for environmental improvement. Payments for forest ecosystem services (PFES) have gained increasing policy acceptance at national and international levels. However, evidence about their implementation is limited and rather mixed. PES design is a complex task. There are a number of PES design features that need careful understanding of the specific ecological and socio-economic context. The aim of this article is to analyse main approaches to PFES and types of PES schemes or financial arrangements with the emphasis on three basic schemes: (i) public schemes or government-financed PES (Pigouvian type), (ii) private schemes or user-financed PES (Coasean type) and (iii) public-private schemes (a mixed type). The empirical part is based on the review of PES schemes implemented in different Forest Europe signatory countries. The main features of PES schemes are described on chosen examples from Slovakia.
\end{abstract}

Key words: financial mechanism, forest functions, payments schemes design.

\section{Introduction}

Three international classification systems are available to classify ecosystem services (ES): Millennium Ecosystem Assessment (MEA), The Economic of Ecosystems and Biodiversity (TEEB) and Common International Classification of Ecosystem Services (CICES). In essence, they relate, to a large extent, to each other; all three include provisioning, regulating and cultural services (Maes, 2013). MEA (2005) also distinguishes supporting ecosystem services that are necessary for the production of all other ecosystem services. Forest ecosystems provide an array of benefits, including protection of soil and water resources, habitat for fish and wildlife, timber and wood fibre, aesthetically pleasing landscapes and the storage of carbon that can help mitigate global warming (Nasi et al., 2002; Kilgore et al., 2017). As ES are mostly public goods, there is usually no market for them 
(Pagiola et al., 2002) that has implications for forest managers as well as for policy makers. If a service has no market, it has no market price (i.e. the price is zero) and the forest owner will not consider the provision of this service in the same way as he or she would for a market good like timber. However, this non-market good or service has a value for the forest owner and for society (Garcia et al., 2018). Provisioning services are equivalents of forest production functions and include production of wood, game and other market products. These goods produced by forest ecosystems can be classified as private goods for which a market mechanism and a price operate as indicators of the limitation of a private farm (Bösch et al., 2018; Nasi et al., 2002; Mavsar et al., 2008). Cultural and supporting ecosystem services are equivalents of non-productive functions of forests and are considered to be public services with open access and inaccessibility from consumption (Table 1). As a result, these services do not have the manufacturer's proprietary rights, the ambiguous claim structure and unfair transaction costs (Sternberg, 1996). As no one is the owner or has rights to these services, and others cannot be excluded from their exploitation or benefits, there is no incentive for recipients to provide ecosystem services in a sustainable way (Daily et al., 2000).

T a b l e 1. Approaches to FES from Slovak law to worldwide classification.

\begin{tabular}{|c|c|c|c|c|}
\hline \multicolumn{3}{|c|}{ Functions of Forests (Act About Forests no. 326/2005 Coll.) } & FES (MAES, 2013) & FES (MA, 2005) \\
\hline \multicolumn{3}{|c|}{ Productive (wood, hunting, non-wooden products) } & Provisioning & \multirow{10}{*}{ Supporting } \\
\hline \multirow{9}{*}{ Non-productive } & \multirow{3}{*}{ Ecological } & Soil protection & \multirow{6}{*}{ Regulating/sustaining } & \\
\hline & & Hydric-water management & & \\
\hline & & Climatic & & \\
\hline & \multirow{6}{*}{ Social } & Health & & \\
\hline & & Nature protection & & \\
\hline & & Water protection & & \\
\hline & & Recreational & \multirow{3}{*}{ Cultural } & \\
\hline & & Cultural & & \\
\hline & & Educational & & \\
\hline
\end{tabular}

A major challenge regarding the delivery of forest ecosystem services (FES) is that many of the provided services are not tradable on the markets, making it difficult to observe their values directly (Forest Europe, 2014; Viszlai et al., 2016). Therefore, information and assessments of forest functions and ecosystems services is important for the design and implementation of related policies and implementation of effective sustainable forest management at the European level (Maes et al., 2013, 2014). Financial instruments are designed to modify behaviour by encouraging private individuals, organisations and businesses to actively participate in supporting ecosystem services (Raitanen et al., 2013). Conceptualising the schemes for the payments for ecosystem services (PES) is becoming an increasingly popular way to manage ecosystems using market-based incentives (Farley, Constanza 2010; Gómez-Baggethun, Muradian, 2015; Prokofieva, 2016). The core idea of PES is simple; users or beneficiaries of these services (Prokofieva, 2016) pay landowners or forest managers for the provision of certain ecosystem services or for a particular forest management strategy for generating the desired ES. Recently, a number of studies have been 
developed across Europe to map operation of PES schemes (Bösch et al., 2018; Smith et al., 2017; OECD, 2010; IUCN, 2009; UNECE, 2005, 2014). We describe the existing approaches to payments for forest ecosystem services (PFES) schemes with examples from Europe.

The aim of the article is to analyse main approaches to payments for FES and existing PFES schemes in Europe, with the emphasis on examples from Slovakia.

\section{Characteristics of PES schemes}

PES are flexible, financial mechanisms for utilisation of available finances for environmental improvement. We can also characterise them as a reward for ensuring positive externalities (Daily, 1997) and their internalisation (Farley, Costanza, 2010; Garcia et al., 2018). Wunder (2015) described PES as voluntary transactions between service users and service providers that are conditional on agreed rules of natural resource management for generating offsite services. He also critically addressed existing definitions of PES, discussed the distinguishing features of PES that differentiate them from other economic incentives and derived a revised definition of PES. Most of the literature refers to PES as a market-based or a market-like mechanism and follows the criteria of Wunder (2005). PES is defined as a scheme that follows the following conditions:

a. it is a voluntary transaction,

b. there is a well-defined environmental service (or a land use likely to secure that service),

c. there is a minimum one service buyer,

d. there is a minimum one service provider who acts as a seller,

e. it is paid if and only if the service provider secures service provision (conditionality).

Understanding how PES mechanisms work in theory and in practice, and knowing their limitations, is crucial for exploiting their full potential as a policy tool for solving complex environmental problems we are confronted with (Prokofieva, 2016). The mechanism of the PES scheme is based on the amount of the payment as shown in Figure 1.

To ensure that PES schemes are successful, it is important to achieve a win-win situation for both sellers and buyers. The payment offered to forest owners or forest managers must exceed the additional benefit they would receive from the alternative forest use (or they would not change their behaviour) and must be less than the value of the benefit to FES users (or users would not be willing to pay for it) (Engel et al., 2008). The minimum PES should be generally expected to cover at least any (private) returns forgone as a result of reduced timber production. The theoretical maximum payment would represent the cumulative value of additional ecosystem service benefits that would accrue to the buyers. Many of these benefits are still hard to quantify (Smith et al., 2013).

A critical issue of PES schemes concerns the main actors involved in them. According to Engel et al. (2008), the actors are:

- Buyers - actual beneficiaries of an ES or 'others' (typically the government, a private company, association, or nongovernmental organisations [NGOs] and international agencies) acting on behalf of the users of the ES.

- $\quad$ Providers - are those actors (land and resource managers, local communities, farmers) who are in a position to safeguard the delivery of the ES and act as sellers.

In many PES schemes, groups of other actors have also been recognised. Governmental and NGOs play an important role in many PES schemes (e.g. Vatn, 2010; Huber-Stearns et al., 2013; Smith et al., 2013). They might be: 


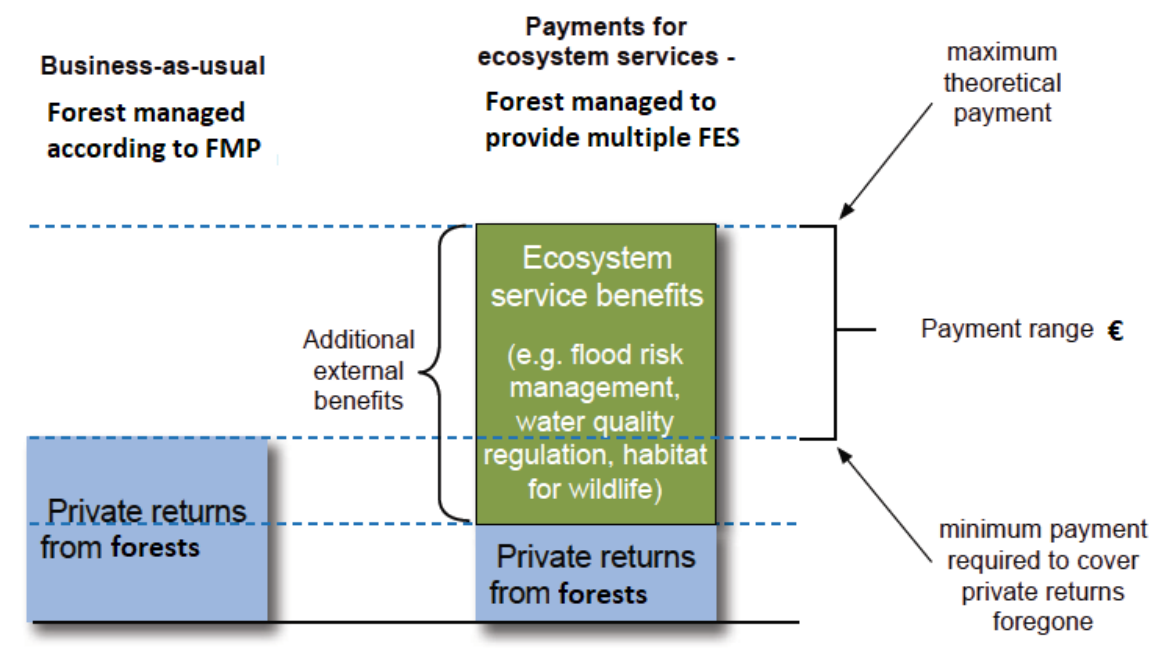

Fig. 1. PES mechanism (adapted from Smith et al., 2013).

- Intermediaries - are those who can serve as agents linking buyers and sellers and can help with scheme design and implementation.

- Knowledge providers - include resource management experts, valuation specialists, land use planners, regulators and business and legal advisors who can provide knowledge essential to scheme development.

A PES scheme can focus on more than one ecosystem service provision. The services being sold are then described as having been 'packed. Ecosystem services can be packaged in three distinct ways (Fig. 2; Smith et al., 2013):

- Bundling: a single buyer, or a consortium of buyers, pays for the full package of ecosystem services that arise from the same parcel of land or body of water, for example, an agro-environment scheme funded by the government on behalf of the wider public.

- Layering: multiple buyers pay separately for the ecosystem services that arise from the same parcel of land or body of water; layering is also sometimes referred to as 'stacking. For example, an area of peatland is restored and yields a range of saleable ecosystem service benefits. The carbon sequestration benefits are purchased by a business, the water quality benefits by a water utility, the flood risk management benefits by the government on behalf of downstream communities and the biodiversity benefits by a wildlife charity on behalf of its membership.

- Piggy-backing: in this case, not all of the ecosystem services generated from a single parcel of land or body of water are sold to buyers. Instead, a single service (or possibly several services) is sold as an umbrella service, whilst the benefits provided by other services accrue to users free of charge (i.e. the beneficiaries 'free ride'). For example, a business pays an upstream land manager for riparian restoration work to reduce the downstream flood risk to its bankside facilities. These improvements simultaneously improve water quality, enhance recreational 
values and provide habitat for wildlife. However, no buyers are found for these additional services, and the benefits they provide to end users are received at no cost.
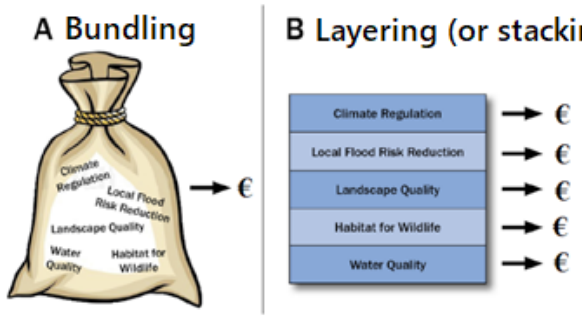

\section{Piggy-backing}

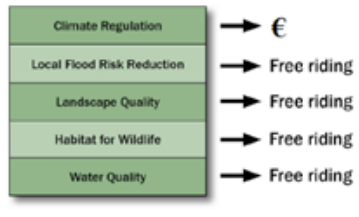

Fig. 2. Approaches to packaging ecosystem services (source: Smith et al., 2013).

\section{PFES scheme types}

A number of alternative approaches to PFES have been designed. According to the financial arrangements, PFES can be divided into three basic schemes (Schomers, Mantzdorf, 2013; Mantzdorf et al., 2013; Mavsar et al., 2008):

- Public schemes or Government-financed PES - in these, a public body, such as a municipality, a national or a local government, is the primary buyer of the ecosystem service, generally a land use or management practice is the general interest whilst also benefiting local concerns. Those buyers act on behalf of ecosystem services users - citizens or general public are the service users (Pigouvian-type).

- Private schemes or User-financed PES - privately owned bodies (such as companies, cooperatives or private individuals) compensate a private landowner for the maintenance of an ecosystem service. Buyers are the actual users of ecosystem services (Coasean type).

- Public-private schemes - a combination of public and private schemes. In these, the seller is a private entity, whilst the buyer (or one of the principal buyers) is also a private individual but represented by a public body. The PES contract is usually administered by a third-party PES-management entity.

According to the five PES criteria (Wunder, 2005), the PES schemes can be divided into another three groups (Zandersen et al., 2009):

- $\quad$ PES core schemes - only schemes that strictly follow the five main criteria - a voluntary transaction between a minimum one buyer and a minimum one seller of a well-defined ES and with a strong conditionality attached.

- PES-like schemes - incentives comply with only some of the five requirements. For example, some programmes may not have buyers paying voluntarily for the service or other programmes may be characterised by a low conditionality or a weak additionality.

- Other economic incentives - a range of economic incentives as PES, where payments are made to achieve higher levels of ES streams in different contexts. 


\section{Methodology}

A document analysis of relevant primary and secondary sources was used to describe PFES and their characteristics. The main classification is based on five Wunder's (2005) criteria for PES schemes. According to them, we searched for specific examples and cases of public, private and public-private PFES schemes across Europe and the Slovak Republic. The description of selected European examples was based on the analysis of available information about PFES schemes from the following PES databases:

- UNECE-FAO database of PES case studies,

- European PES repository of Case Studies on PES-for-W,

- $\quad$ Forest Europe Web Portal on Forest Ecosystem Services,

- $\quad$ Ecosystem Marketplace.

For the purpose of this article, the UNECE list of PFES examples and Ecosystem Marketplace database were used as the main information sources. The interactive Ecosystem Markets Map displays information about projects that conserve, restore or support sustainable management of ecosystem services through ecosystem markets and market-based mechanisms. Examples from Slovakia were described based on the available information and the literature review, supported by the personal interviews with actors presented as ES providers. The individual examples were further described in terms of the actors involved in PES schemes, the supported ecosystem services and the packaging of the ecosystem services. The results of the comparison of the PFES schemes were elaborated using Wunder's (2005) PES criteria. All examples were used to support the existence of described theoretical approaches of PFES in Europe and Slovakia.

\section{Results and discussion}

PFES received a lot of academic attention in the past years (Schomers, Matzdrof, 2013; Prokofieva, 2016). Different PFES schemes have been developed across Europe to address problems with ensuring the provision of FES, nature conservation, biodiversity, water quality and other environmental concerns. A widely accepted policy strategy is to implement direct PES to increase the incentives of forest owners, public or private for providing such services.

From the point of the supported services, we divide PFES schemes into payments for forest services (PFS) and/or biodiversity (BD), payments for watershed services (PWS) and water quality improvement (UNECE, 2014). The Ecosystem Market Place Map uses different filter for distinguishing between the projects, that aim to support the ecosystem services, that generate: (i) the carbon offsets; (ii) the wetland and stream offsets; (iii) habitat offsets and (iiii) investments in watershed health. The Market Place database shows the total number of 137 PES projects across Europe, of which 22 focus on providing/conserving terrestrial carbon, 49 focus on providing/conserving species and habitats and 66 provide/conserve watersheds. There is no project providing or conserving wetlands (Ecosystem Marketplace, 2018). The UNECE list reveals another 48 schemes across Europe. Those databases do not contain all projects related to forests and are open for suggestions. Most PFES schemes focus on watersheds (UNECE, 2014; Ecosystem Marketplace, 2018).

Most of the PES schemes in the European Union are public-private ones (Ecosystem Marketplace, 2018; UNECE, 2014). Mixed schemes are based on different bilateral agreements, collective fund actions or compensatory mitigation (Ecosystem Marketplace, 2018). At present, the Ecosystem Marketplace and UNECE identify approximately 47 public PFES schemes at the European level. The issue of PES has reached the political agenda of the European Union, mainly through national rural development programmes (Kati et al., 2015; Sarvašová et al., 2013).

In Slovakia, public schemes are predominantly used to ensure FES provision. We identified three types of public PFES schemes: (1) forest land tax relief for protective and special purpose forests, (2) refunds for the restriction of ownership rights and (3) forestry support for non-pro- 
ductive forest functions (Table 2). Private schemes are very rare in Slovakia. Besides these national schemes, the Rural Development Programme also contains measures that can be considered as PFES, namely, Natura 2000 payments.

Most European countries have used a variety of incentives to encourage ecosystem services of forests (Mercer, 2004). Tax incentives include reduced or differed property, estate and inheritance taxes, favourable tax credits and deductions, favourable capital gains treatment of timber income as well as incentives linked to specific forestry practices such as wildlife protection, recreation and reforestation (Ma et al., 2014). The forest land tax relief for protective and special purpose forests in Slovakia represents the support for all services that are part of the forest ecosystem on the specific forestland. As Mercer (2004) pointed out, the protective role of forest ecosystems provides public goods (e.g. biodiversity, carbon sequestration, wildlife habitat, recreation, tourism), whose production may or may not conflict with private goods produced from the ecosystem such as timber, and tax incentives are way how to support the forest owners. A similar example can be found in France, where numerous fiscal mechanisms apply to protected areas, including land tax exemptions in Natura 2000 areas and land revenue tax reductions for expenses for the preservation or restoration of protected areas (IUCN 2009). In the case of this instrument, however, mainly the 'piggy-backing' principle is applied. The land tax relief is granted for a particular case of support for non-productive forest functions based on subcategories of special purpose forests and protective forests, although the other services are 'free riders'. Because the tax relief is not a direct payment and the principle of voluntariness or conditionality is not adhered, we can consider it as other economic incentives supporting FES. The fulfilment of the irreplaceable functions of forests and their preservation is also supported in the European countries by the environmental taxes (Schlegelmilch, 2002), from which governments create funds to support ecosystem services (Miceikiene, Butvilaite, 2015).

In the water sector, public schemes usually target services to secure supply (quality and quantity), flood protection and erosion control usually by the provision of financial incentives to encourage more sustainable land use (UNECE, 2014). The example from Slovakia is a private PFES water scheme between the Military Forests and Estates of the Slovak Republic (MFE), owned by the state, but more or less act as private company and local water management and supply company (Podtatranská vodárenská prevádzková spoločnost', a.s.). A significant part of the territory of MFE includes important water areas classified into the first to third degrees of water protection. Many watercourses are sources of drinking water. In some places, water payment schemes are introduced to provide drinking water for local use (e.g. Branch office of the State Military Forest Enterprise in Kežmarok). The payment scheme for water is a long-term business relationship, lasting for more than 10 years. Contracts and prices are negotiated with the approval of the Regulatory Office for Network Industries of the Slovak Republic for 3 years. In these areas, the MFE provides water management in accordance with the area needs and environmental regulations. As Bujnovský (2015) stated, achieving the good ecological and chemical status of the land can have impact on improving water status and increasing the capacity of some ecological functions. The company manages and maintains forest land and is responsible for land improvements and stream dikes. In this case, the 'piggy-backing' principle is applied, where a single service generated by the water managing authority (MFE) is sold to one specific buyer (the local water management and supply company). The well-known example of PES for water from other European countries 


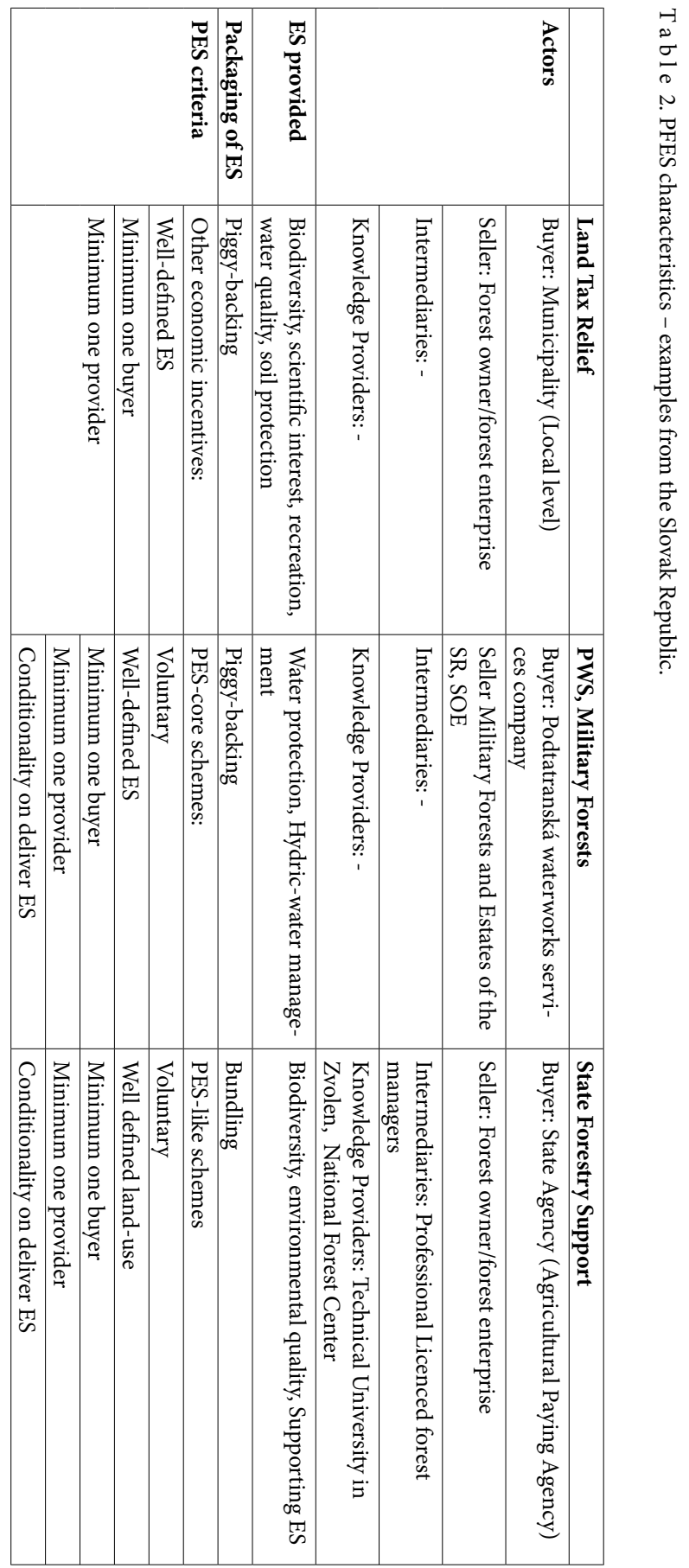


is implemented by Vittel (Nestlé Waters) in north-eastern France. This scheme illustrates how a 'narrow' PES would look like (Perrot-Maitre, 2006).

PFES are also considered as tools to help maintain the multi-functional role of forests through supporting forest owners to adopt management practices that maximise environmental and social benefits (UNECE, 2014). Environmentally friendly or sustainable forest management has, nowadays, become a dominant theme in forestry throughout Europe. This paradigm recognises that forests are managed for a wide range of ecological, economic and social benefits (Cubbage et al., 2007). Various examples of uniform payments for environmentally friendly management practices could be found across European countries (OECD, 2010; Stanton et al., 2010; IUCN, 2009). These payments are direct financial support that affects the behaviour of forest owners through motivational stimuli (Šálka, 2006). The main aim of the Forestry Support for Non-Productive Forest Functions is to stimulate forest managers to ensure ecosystem services in the territory of the Slovak Republic in accordance with the forest management plan (Kicko, 2017). Financial support is, in principle, applicable to all FES (Šálka, Dobšinská, 2013). The state motivates forest owners or managers to apply sustainable forest management principles, which will lead to increased production of nonproductive forest functions. Sustainable forest management (silviculture) creates multi-storeyed and rich mixed forest stands, with forest management emulating natural processes and seamless replacement of generations (Schütz et al., 2016). Understanding of the functions and processes of forest ecosystems is crucial for sustainable forest management practices (Machar, 2013). The government pays for the full package of ecosystem services that arise from the specific forestland according to the forest management plan. Smith et al. (2013) revealed that payments for sustainable forest management practices are made for a full suite of provided FES, as some proportions of the population will benefit from all of them. 'Bundling' of FES might provide a way for forest owners to get paid for more benefits they are providing (Deal et al., 2012). The concept of bundling can promote the integration of multiple ecological benefits (Collins, Larry, 2008; Venter et al., 2009; La Rocco, Deal, 2011).

\section{Conclusion}

Forests provide a wide range of ecosystem services. Unfortunately, many of the ecosystem services provided by forests are not directly paid for, and this may result in a lower provision than is socially optimal. The underlying reasons are that many ecosystem services are either public goods such as carbon sequestration or common goods such as water supply and, therefore, are non-market goods. Implementing PES schemes has become one of the policy strategies to ensure ecosystem services provision. Although several databases mapping PES schemes across Europe exist, they are either outdated or do not contain all relevant information.

Our analysis shows that only a few 'core' PES schemes are applied in Europe. Usually, the payments have a mixed public-private character. The European Union plays a strong role, and its Rural Development Fund provides financial support for biodiversity conservation or other environmental issues under the agro-environment pillar, which can be considered as a PES scheme.

Three types of public PFES schemes were identified in Slovakia: (1) forest land tax relief for protective and special purpose forests, (2) refunds for the restriction of ownership rights 
and (3) Forestry support for non-productive forest functions. Private PFES schemes have been identified so far only for watershed services and water quality improvement in MFE. As yet it is an open problem how appropriate payment schemes considering different types of forest ownerships and FES should look like and what kind of supporting policies are needed.

\section{Acknowledgements}

This article was supported by the Slovak Research and Development Agency (APVV-15-0715 and APVV-17-0232) and Internal Project Agency of Technical University in Zvolen (IPA 1/2018). The empirical results were obtained from the framework of COST CA15206 PESFOR-W.

\section{References}

Bösch, M., Elsasser, P., Franz, K., Schneider, H., Lorenz, M., Moning, C., Olschewski, R., Roedl, A., Schröppel, B. \& Weller P. (2018). Forest Ecosystem Services in rural areas of Germany - insights from the national TEEB study. Ecosystem Services, 31(Part A), 77-83. DOI: 10.1016/j.ecoser.2018.03.014.

Bujnovský, R. (2015). Evaluation of the ecosystem services of inland waters in the Slovak Republic - to date findings. Ekológia (Bratislava), 34(1), 19-25. DOI: 10.1515/eko-2015-0003.

Collins, S. \& Larry B. (2008). Caring for our natural assets: an ecosystems services perspective. In R.L. Deal (Ed.), Integrated restoration of forested ecosystems to achieve multi-resource benefits (pp. 1-11). Proceedings of the $2007 \mathrm{National}$ Silviculture Workshop. Portland: U.S. Department of Agriculture, Pacific Northwest Research Station.

Cubbage, F., Harou, P. \& Sills E. (2007). Policy instruments to enhance multi-functional forest management. Forest Policy and Economics, 9(7), 833-851. DOI: 10.1016/j.forpol.2006.03.010.

Daily, G.C., Söderqvist, T., Aniyar, S., Arrow, K., Dasgupta, P., Ehrlich, P.R., Folke, C., Jansson, A.-M., Jansson, B.-O., Kautsky, N., Levin, S., Lubchenco, J., Mäler, K.-G., Simpson, D., Starrett, D., Tilman, D. \& Walker B. (2000). The value of nature and the nature of value. Science, 289(5478), 395-396. DOI: 10.1126/science.289.5478.395.

Daily, G.C. (1997). Nature's services: societal dependence on natural ecosystems. Washington: Island Press.

Deal, R.L., Cochran, B. \& LaRocco G. (2012). Bundling of ecosystem services to increase forestland value and enhance sustainable forest management. Forest Policy and Economics, 17, 69-76. DOI: 10.1016/j.forpol.2011.12.007.

Ecosystem Marketplace Database. https://www.forest-trends.org/project-list/\#s

Engel, S., Pagiola, S. \& Wunder S. (2008). Designing payments for environmental services in theory and practice - An overview of the issues. Ecological Economics, 65, 663-674. DOI: 10.1016/j.ecolecon.2008.03.011.

Farley, J. \& Costanza R. (2010). Payments for ecosystem services: From local to global. Ecological Economics, 69, 20602068. DOI: 10.1016/j.ecolecon.2010.06.010

Forest Europe Expert Group and Workshop on a pan-European approach to valuation of forest ecosystem services. Belegrade Workshop, 24-25 September 2014, Final Report, https://www.foresteurope.org/documentos/Report_Valuation_FES_ForestEurope.pdf

Garcia, S., Abildtrup, J. \& Stenger A. (2018). How does economic research contribute to the management of forest ecosystem services?. Ann. For. Sci., 75(2), 53. DOI: 10.1007/s13595-018-0733-7.

Gómez-Baggethun, E. \& Muradian R. (2015). In markets we trust? Setting the boundaries of market-based instruments in ecosystem services governance. Ecological Economics, 117, 217-224. DOI: 10.1016/j.ecolecon.2015.03.016.

Huber-Stearns, H.R., Goldstein, J.H. \& Duke E.A. (2013). Intermediary roles and payments for ecosystem services: a typology and program feasibility application in Panama. Ecosystem Services, 6, 104-116. DOI: 10.1016/j.ecoser.2013.09.006.

IUCN Regional Office for Europe \& IUCN Environmental Law Centre (2009). Final report study on the economic value of groundwater and biodiversity in European forests. http://ec.europa.eu/environment/forests/pdf/grounwater_report.pdf.

Kati, V., Hovardas, T., Dieterich, M., Ibisch, P.L., Mihok, B. \& Selva N. (2015). The challenge of implementing the European network of protected areas Natura 2000. Conserv. Biol., 29(1), 260-270. DOI: 10.1111/cobi.12366.

Kicko, P. (2017). Systém podpory v lesnom hospodárstve na plnenie mimoprodukčných funkcií lesov. In Financovanie podnikov v lesnom hospodárstve (pp. 109-116). Zborník vedeckých prác. Zvolen: Technická univerzita vo Zvolene.

Kilgore, M.A, Ellefson, P.B, Funk, T.J. \& Frey G.E. (2017). State property tax incentives for promoting ecosystem goods and 
services from private forest land in the United States: a review and analysis. e-Gen. Tech. Rep. SRS-228. Asheville: U.S. Department of Agriculture Forest Service, Southern Research Station.

LaRocco, G. \& Deal R.L. (2011). Giving credit where credit is due: Increasing landowner compensation for ecosystem services. Gen. Tech. Rep. PNW-GTR-842. Portland: U.S. Department of Agriculture, Forest Service, Pacific Northwest Research Station.

Ma, Z., Butler, B.J., Catanzaro, P.F., Greene, J.L., Hewes, J.H., Kilgore, M.A., Kittredge, D.B. \& Tyrrell M. (2014). The effectiveness of state preferential property tax programs in conserving forests: Comparisons, measurements, and challenges. Land Use Policy, 36, 492-499. 10.1016/j.landusepol.2013.09.016.

Maes, J., Teller, A., Erhard, M., Liquete, C., Braat, L., Berry, P., Egoh, B., Puydarrieux, P., Fiorina, Ch., Santos-Martín, F., Paracchini, M.L., Keune, H., Wittmer, H., Hauck, J., Fiala, I., Verburg, P.H., Condé, S., Schägner, J.P., San Miguel, J., Estreguil, Ch., Ostermann, O., Barredo, J.I., Pereira, H.M., Stott, A., Laporte, V., Mainer, A., Olah, B., Royo Gelabert, E., Spyropoulou, R., Petersen, J.E., Maguire, C., Zal, N., Achilleos, E., Rubin, A., Ledoux, L., Brown, C., Raes, C., Jacobs, S., Vandewalle, M., Connor, D. \& Bidoglio G. (2013). Mapping and Assessment of Ecosystem and their Services. An analytical framework for ecosystem assessments under action 5 of the EU Biodiversity Strategy to 2020. Luxemburg: Publication office of the European Union. DOI: 10.2779/12398.

Maes, J., Teller, A., Erhard, M., Murphy, P., Paracchini, M.L., Barredo, J.I., Grizzetti, B., Cardoso, A., Somma, F., Petersen, J.E., Meiner, A., Gelabert, E.R., Zal, N., Kristensen, P., Bastrup-Birk, A., Biala, K., Romao, C., Piroddi, Ch., Egoh, B., Florina, Ch., Santos, F., Naruševičius, V., Verboven, J., Pereira, H., Bengtsson, J., Kremena, G., Pedroso-Marta, C., Snäll, T., Esterguil, Ch., San Miguel, J., Braat, L., Gret-Regamey, A., Perez-Soba, M., Degeorges, P., Beaufaron, G., Lillebø, A., Marak, A.D., Liquette, C., Condé, S., Moen, J., Östergard, H., Czúcz, B., Drakou, E.G., Zulian, G. \& Lavalle C. (2014). Mapping and Assessment of Ecosystem and their Services. Indicators for ecosystem assessments under action 5 of the EU Biodiversity Strategy to 2020. Luxemburg: Publication office of the European Union. DOI: 10.2779/75203.

Machar, I. (2013). Applying landscape ecological principles in sustainable forest management of the floodplain forest in the temperate zone of Europe. Ekológia (Bratislava), 32(4), 369-375. DOI: 10.2478/eko-2013-0034.

Matzdorf, B., Sattler, C. \& Engel S. (2013). Institutional frameworks and governance structures of PES schemes. Forest Policy and Economics, 37, 57-64. DOI: 10.1016/j.forpol.2013.10.002.

Mavsar, R., Weiss, G., Ramčilović, S., Palahí, M., Rametsteiner, E., Tykkä, S., van Apeldoorn, R., Vreke, J., van Wijk, M., Prokofieva, I., Rekola, M. \& Kuuluvainen J. (2008). Study on the development and marketing of non-market products and services. Study report.

MEA (Millennium Ecosystem Assessment) (2005). Ecosystems and Human Well-being: Synthesis. https://www.millenniumassessment.org/documents/document.356.aspx.pdf

Mercer, D.E. (2004). Policies for encouraging forest restoration. In J.A. Stanturf \& P. Madsen (Eds.). Restoration of boreal and temperate forests (pp. 97-109). Boca Raton: CRC Press.

Miceikiene, A. \& Butvilaite A. (2015). Evaluation of the experience in environmental tax reforms in the EU countries. European Scientific Journal, 11(19), 280-299.

Nasi, R., Wunder, S. \& Campos J. (2002). Forest ecosystem services: Can they pay our way out of deforestation? Paper presented at the roundtable on forests sponsored by the Global Environment Facility; 11 March, New York. Bogor (Indonesia): CIFOR (Center for International Forestry Research), for Global Environment Facility.

OECD (2010). Paying for biodiversity: Enhancing the cost-effectiveness of payments for ecosystem services. OECD Publishing.

Pagiola, S., Bishop, J. \& Landell-Mills N. (Eds.) (2002). Selling forest environmental services. Market-based Mechanisms for Conservation and Development. London: Earthscan.

Perrot-Maitre, D. (2006). The Vittel payments for ecosystem services: a "perfect" PES case. London: International Institute for Environment and Development.

Prokofieva, I. (2016). Payments for Ecosystem Services-the Case of Forests. Current Forestry Reports, 2(2), 130-142. DOI: $10.1007 / \mathrm{s} 40725-016-0037-9$.

Raitanen, E., Simila, J., Siikavirta, K. \& Primmer E. (2013). Economic instruments for biodiversity and ecosystem service conservation \& the EU state aid regulation. Journal of European Environmental \& Planning Law, 10(1), 6-28. DOI: 10.1163/18760104-01001002.

Sarvašová, Z., Šálka, J. \& Dobšinská Z. (2013). Mechanism of cross-sectoral coordination between nature protection and forestry in the Natura 2000 formulation process in Slovakia. J. Environ. Manag., 127, S65-S72. DOI: 10.1016/j.jenvman.2012.06.005.

Schlegelmilch, K. (2002). Overview and recent experiences with ecological tax reforms in Europe. In J. Holst, D. Lee \& E. Olson (Eds.), Finance for sustainable development: Testing new policy approaches (pp. 221-245). New York: United Nations. 
Schomers, S. \& Matzdorf B. (2013). Payments for ecosystem services: A review and comparison of developing and industrialized countries. Ecosystem Services, 6, 16-30. DOI: 10.1016/j.ecoser.2013.01.002.

Schütz, J.P., Saniga, M., Diaci, J. \& Vrška T. (2016). Comparing close-to-nature silviculture with processes in pristine forests: lessons from Central Europe. Ann. For. Sci., 73(4), 911-921. DOI: 10.1007/s13595-016-0579-9.

Smith, A.C., Harrison, P.A., Pérez Soba, M., Archaux, F., Blicharska, M., Egoh, B.N., Erős, T., Fabrega Domenech, N., György, Á.I., Haines-Young, R., Li, S., Lommelen, E., Meiresonne, L., Miguel Ayala, L., Mononen, L., Simpson, G., Stange, E., Turkelboom, F., Uiterwijk, M., Veerkamp, C.J. \& de Echeverria V.W. (2017). How natural capital delivers ecosystem services: a typology derived from a systematic review. Ecosystem Services, 26, 111-126. DOI: 10.1016/j. ecoser.2017.06.006.

Smith, S., Rowcroft, P., Everard, M., Couldrick, L., Reed, M., Rogers, H., Quick, T., Eves, Ch. \& White C. (2013). Payments for ecosystem services: a best practice guide. London: Defra.

Stanton, T., Echavarria, M., Hamilton, K. \& Ott C. (2010). State of watershed payments: an emerging marketplace. State of watershed payments: an emerging marketplace. https://www.forest-trends.org/publications/state-of-watershedpayments/

Sternberg, E. (1996). Recuperating from market failure: planning for biodiversity and technological competitiveness. Public Administration Review, 56, 21-34.

Šálka, J. (2006). Analýza verejnej politiky v lesníctve. Zvolen: Technická Univerzita vo Zvolene.

Šálka, J. \& Dobšinská Z. (2013). Policy Analysis for assuring forest ecosystem externalities. Zvolen: Technická Univerzita vo Zvolene.

UNECE (2005). Seminar on environmental services and financing for the protection and sustainable use of ecosystems. Geneva, 10-11 October 2005. National reports. http://www.unece.org/env/water/meetings/payment_ecosystems/seminar.htm.

UNECE (2014). The value of forests payments for ecosystem services in green economy. Geneva Forest and Timber Study Paper 34. https://www.unece.org/fileadmin/DAM/timber/publications/SP-34Xsmall.pdf

Vatn, A. (2010). An institutional analysis of payments for environmental services. Ecological Economics, 69(6), 1245-1252. DOI: 10.1016/j.ecolecon.2009.11.018.

Venter, O., Laurance, W., Iwamura, T., Wilson, K., Fuller, R. \& Possingham H. (2009). Harnessing carbon payments to protect biodiversity. Science, 326(5958), 1368. DOI: 10.1126/science.1180289.

Viszlai, I., Barredo, J.I. \& San-Miguel-Ayanz J. (2016). Payments for forest ecosystem services: SWOT analysis and possibilities for implementation. Joint Research Centre.

Wunder, S. (2005). Payments for environmental services: some nuts and bolts. CIFOR Occasional Paper. Bogor: Center for International Forestry Research.

Wunder, S. (2015). Revisiting the concept of payments for environmental services. Ecological Economics, 117, 234-243. DOI: 10.1016/j.ecolecon.2014.08.016.

Zandersen, M., Grønvik Bråten, K. \& Lindhjem H. (2009). Payment for and management of ecosystem services - Issues and options in the Nordic context payment for and management of ecosystem services. Copenhagen: Nordic Council of Ministers. 